\section{Philip Jay, 1898-1974 President of the IADR, 1943-1944}

It is typical of the value that Philip Jay placed on life that he dedicated his career to improving the quality of life for others. As a bacteriologist, educator, and humanist, this versatile man was one of the foremost contributors to the study of the cause and the cause of dental caries.

Born in Detroit on June 5, 1898, Philip Jay grew up there and entered the University of Michigan in 1919. For two years he majored in journalism, but influenced by a classmate's brother, a successful Detroit dentist, he transferred to the School of Dentistry. After completing the curriculum in dentistry, he stayed on another year for graduate study in dental pathology and received an MS degree in 1924.

Jay practiced dentistry for a year in Deftroit, but in 1925 joined the Department of Bacteriology at the University of Rochester School of Medicine and Dentistry. There he worked with the noted bacteriologist, Stanhope Bayne-Jones. For four years, Philip studied the bacteriologic aspects of dental caries in an attempt to determine ways of attacking oral lactobacilli.

In 1929, Russell W. Bunting, then professor of oral pathology and histology at the School of Dentistry at the University of Michigan, invited Philip Jay to direct the bacteriologic studies of a project he (Bunting) had conceived to determine the cause and control of dental caries. The Michigan Dental Caries Research Group, as it was known, conducted some of the most definitive research that had been accomplished up to that time on the nature of dental caries.

Instrumental in these studies, Jay was able to demonstrate the positive relationship between oral lactobacillus activity and carbohydrate intake to dental caries. This was a revolutionary concept and it proved to be one of the most significant discoveries in the long search for the cause of the disease.

His findings led him to establish in 1935 the

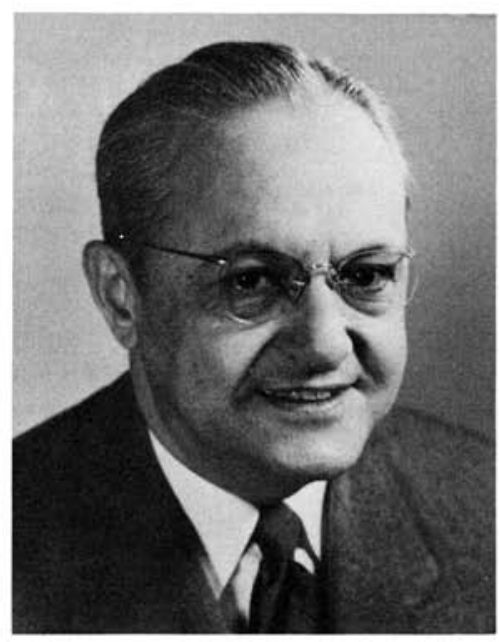

Michigan Dental Caries Control Program, a nationwide diagnostic and caries control service that tested salivary samples for lactobacilli growth levels and on that basis predicted caries activity for the individual. Jay's "remote control" anticaries program provided a unique service to thousands of patients around the coun. try-former colleagues remember hearing him joke "We've got the best spit in the country!" Following Jay's example, many state public health laboratories and several dental schools set up similar caries diagnosis and control programs.

When the effect of fluorides as a caries preventive measure was discovered, Philip Jay played a major role in the drama of fluoridation, both inside and outside the laboratory. As a consultant to the US Public Health Service, Jay took part in bacteriologic surveys in the epidemiologic studies in the Texas Panhandle, Arkansas, and Illinois, studying populations where fluorine occurred naturally in the water supply. In the 1940 s he was among those responsible for the initiation of the fa- 
mous Public Health Service fluoridation study in Grand Rapids and a similar study in Newburgh, NY.

When the results of these studies proved that a large-scale method of reducing dental caries finally was available, Philip Jay became one of fluoridation's most ardent supporters. He was in great demand as a speaker before dental societies and public hearings; he traveled all over the country, often to remote rural areas to spread the word about fluoridation. Jay's skills in persuasion and his dedication to the fight against dental caries did much to promote the ultimate widespread acceptance of public fluoridation.

Jay's work had become nationally knownin 1941 he was awarded an honorary DS degree by Washington University and he was elected the 20th president of the IADR in 1943. In 1948, he was made a full professor in the Department of Oral Biology-Bacteriology in the School of Dentistry, where he had remained as a teacher after the conclusion of the Michigan Dental Caries Research Group project in 1937.

In 1958, Phil Jay was awarded the Fauchard Gold Medal for distinguished service to den- tistry for his work relating carbohydrate intake to dental caries, and in 1964 he was again honored by being the first to receive the Distinguished Service Award of the Michigan Public Health Association. In 1967, after 38 years on the faculty of the School of Dentistry at Michigan, Philip Jay retired from professional life. After such a full career, he put up his microscope, his books, and his suitcases and spent his remaining years entirely removed from any sort of professional pursuits. As he said on his retirement, "A great deal of mv life has had to be spent in travel. I'm just getting to be an old man and it simply is not fun anymore. When I do hear a jet over my house, I will travel-into my kitchen to mix a martini."

On December 22, 1974, Philip Jay died after a long illness. All who knew him were saddened at the loss of the kind man whose warmth, humor, and graciousness enriched their lives.

$$
\begin{aligned}
& \text {-James K. Avery } \\
& \text { Professor of Dentistry } \\
& \text { University of Michigan } \\
& \text { School of Dentistry } \\
& \text { Past-President, IADR }
\end{aligned}
$$

\title{
International Association for Dental Research
}

\author{
OFFICERS OF THE ASSOCIATION \\ President: David B. ScotT, Case Western Reserve University, Cleveland \\ President-Elect: Harold M. Fullmer, University of Alabama, Birmingham \\ Vice-President: GEORge S. BEAGRIE, University of Toronto, Canada \\ Secretary-Trensurer: ARTHUR R. FRECHETTE, IADR Office, Chicago \\ Ass't Sec'y-Treas: JoHN P. WATERHOUSE, University of Illinois, Chicago \\ Acting Editor: MAYNARd K. HINE, Indiana University-Purdue University at Indianapolis
}

\section{DIVISION AND GROUP REPRESENTATIVES TO THE ASSOCIATION COUNCIL*}

$\begin{array}{ll}\text { Division or Group } & \text { Representatives } \\ \text { American } & \text { H. M. Myers } \\ & \text { H. M. Fullmer } \\ \text { Australia and } & \text { R. J. Gibbons } \\ \text { New Zealand } & \text { J. K. Harcourt } \\ \text { British } & \text { T. Gotjamanos } \\ & \text { G. N. Jenkins } \\ & \text { E. A. Marsland }\end{array}$

Division or Group
Continental European
Israel
Japanese
Scandinavian
South African
Groups

\author{
Representatives \\ M. R. Pourtois \\ R. Frank \\ Y. Michaeli \\ Y. Kawamura \\ M. Onisi \\ K. A. Selvig \\ O. Fejerskov \\ D. H. Retief \\ L. Cohen
}

* For addresses consult IADR Directory, Special Commemorative Supplement, J Dent Res, Vol 48, September 1969 and Addendum, Vol 50, March 1971. 